\title{
ATTITUDES OF PHYSICAL EDUCATION STUDENTS (LAST UNIVERSITY YEAR) AND PHYSICAL EDUCATION TEACHERS TOWARD TEACHING CHILDREN WITH PHYSICAL DISABILITIES IN GENERAL PHYSICAL EDUCATION CLASSES IN BULGARIA
}

Anna Petkova*, Martin Kudláček**, Elena Nikolova***

\author{
*Faculty of Kinesiology and Rehabilitation Sciences, Catholic University, Leuven, Belgium \\ **Faculty of Physical Culture, Palacký University, Olomouc, Czech Republic \\ ***Teacher`s Faculty, National Sports Academy "Vassil Levski”, Sofia, Bulgaria
}

\begin{abstract}
Attitudes of teachers is an important determinant of behavior in educational settings (Avramidis \& Norwich, 2002), and on going discussion suggests it is possible to predict behavior from intentions (Ajzen, 2005). The purpose of this study was to describe the attitudes and predictors of intention toward inclusion of students with physical disabilities in general physical education classes of Bulgarian physical education teachers (PET) and last year university students (LYUS). The ATIPDPE-BG instrument was used to measure attitudes of LYUS from the National Sports Academy "Vassil Levski", Sofia, Bulgaria and Bulgarian PET. Participants were in total 110 (55 females and 55 males), 50 LYUS and 60 PET. An average age of LYUS is 22.65 years, and PET is 35.6 years. The software package SPSS 13.0 was used to analyse results via one-way ANOVA and multiple regression analysis. Overall positive attitudes were displayed for the students in contrast to teachers, though no significant differences between males and females were found (F $=0.11, p=0.74)$. Attitudes were found to be the strongest predictor of intentions, accounting for $43 \%$ of variance $\left(r^{2}=0.44\right)$.
\end{abstract}

Keywords: attitudes, inclusion, physical educators, physical education, students with disabilities and special education needs, physical disability

\section{INTRODUCTION}

Those who have been granted the status of disabled persons in Bulgaria are approximately $9 \%$ and on the increase (National Statistical Institute, 2011). The Bulgarian Constitution states that it is unlawful to discriminate against any person, including race/ethnicity, religion/belief, age, disability and sexual orientation. Article 53 of the Constitution guaranteed the right to education for all citizens.

The research towards inclusion in general physical education, and more importantly relating to attitudes towards inclusion in this setting, be conducted. Inclusion aims to provide full access to schools and facilities, and equal opportunities for all students, regardless of their ability. This research study will focus upon inclusion of students with physical disabilities in general physical education classes.
Inclusion consists of educating all students, regardless of their ability or disability level, together in one educational environment, while meeting the needs of each of these individuals. Inclusion is defined as the education of all children with disabilities (mild to severe) in regular education even if special recourses are needed to make it effective (Block \& Vogler, 1994). According to Sherrill (2004), exceptions to this practice may be the population with severe to profound intellectual disability and/or multiple disabilities that make success in the classroom of regular school very difficult or impossible. Regarding physical education, "Inclusion is the practice of placing many different kinds of students in general physical education and in this environment general physical education teachers will make the necessary changes in didactics, pedagogy, and curriculum to assure that all students will 
achieve their physical education goals and feel safe, happy, comfortable, and successful in the physical education setting" (Kudlacek, 2001, p. 190). The aim of inclusion is to ensure that all students receive adequate instruction and physical activity without any student's skills or cognition being negatively affected (Block \& Zeman, 1996; Vogler, Koranda \& Romance, 2000).

Inclusion in general schools has many benefits both for students with and without disabilities. For example, Mrug and Wallander (2002) point out that students with special education needs (SEN) have the same possibilities and opportunities to participate as their non-disabled counterparts in school and social events. Students without disabilities: learn to approach children with different characteristics (Romer \& Haring, 1994), develop empathy and acceptance of individual children's differences (Lieber, Capell, Sandal, Wolfberg, Horn \& Bechman, 1998), and become more aware and more responsive to other children's needs (Peck, Carlson \& Helmstetter, 1992). Finally, inclusive education gives the opportunity for the development of positive attitudes of students without disabilities toward peers with SEN (Mrug \& Wallander, 2002; Salisbury, Gallucci, Palombaro \& Peck, 1995).

The distribution of integrated students with SEN by levels of education shows that the largest number is reported in the primary school level $46,5 \%$, followed by middle school level $37 \%$, and pre-school level 10,7\%. The lowest number is reported in secondary schooling - only $5,7 \%$, which could be explained by the lack of resources during early education (Data provided by the Ministry of Education, Youth and Science under the Access to Public Information Act, letter dated 15th July 2010; National Conference of the Resource Centres (June 2010) - report, unpublished).

According to information from the resource centers to support inclusive education of children and pupils with special educational needs are educated 8,925 children and pupils with special educational needs (SEN) in 2010. Comparative data shows that in 2009 their number was 7,957. Analyzing this data allows to take into account an increase in the number of children and pupils with SEN by $12 \%$. At the same time increased the number of schools and kindergartens, which creates a supportive environment for inclusive education of children and pupils with SEN. In 2010 the number of such schools and kindergartens was 1,619 $(1,185$ schools and 434 kindergartens) in 2009 1,018 . The data show an increase by $7 \%$.

Disability and attitudes are two important subjects that require thorough understanding when researching inclusive education. It is for this reason that information regarding types of physical disabilities is included, as is a break down of the attitude-behavior relationship, and two main behavior theories; the theory of reasoned action and the theory of planned behavior, which will be included in the design of the questionnaire instrument used during this study.

Once the theory behind attitudes has been explained, information retrieved from previous studies on inclusive education will be provided, particularly in relation to the attitudes of students without disabilities towards inclusion, the attitudes of teachers and students, who are studying the last year Bachelor degree towards inclusion. This will therefore provide a strong basis of knowledge and understanding regarding previous findings so as to compare and justify this current research with supportive evidence.

Attitude refers to whether a person is in favour of performing a certain behavior or not, and is a function of psychological behavioral beliefs. Attitude consists of two components: a) Behavioral beliefs: include perceived consequences of a behavior, and $b$ ) Outcome evaluations: refer to the corresponding positive or negative judgements about the consequences. It has been suggested that attitude is a connotation of behavior (Meegan \& MacPhail, 2006), and as such, can be considered a persuasive influence on a range of behaviors (Ajzen, 2005). 
For Krech, Cruchfield and Ballachey, attitudes are "an enduring system of three components centering about a single object: the belief about the object (the cognitive component), the affect connected with the object (the feeling component) and the disposition to take action with respect to the object (the action tendency component).

The commonly used theory of changing attitudes towards individual with SEN is the theory of planned behavior. At the centre of the Theory of Planned Behavior (TPB) lies the individual's intention. According to Ajzen (1991), the stronger the intention to engage in a behavior, the higher the probability for that behavior to occur should be. The author takes into consideration many factors that might influence a person to act in a certain way. One of such factors is whether the person has control over the situation or not (perceived behavioral control). If the task seems difficult, in other words if the person sees many obstacles keeping him from achieving his goal, then he will be less likely to act in the desired way. An equally important factor is attitude, which may be negative or positive, such as subjective norms, which include our beliefs of how others want us to behave. Ajzen' s theory of behavior states that the outcome is a result of certain preconditions: attitude, subjective norm and perceived behavioral control. These three predict whether the person arrives or not at intention (motivation) to behave a certain way. Multiple studies show that there's a direct relationship between the three: attitudes, subjective norms and intention and consequently with behavior.

In regards to Adapted Physical Education (APE), Planned Behavior Theory can be applied in this light: Teachers with positive attitude towards inclusion, stronger subjective norms and higher perceived behavioral control are more likely to have stronger intention to practice inclusion and consequently would show more "inclusive" behavior (Ajzen \& Driver, 1992). Many studies have begun to help both general and adapted physical educators understand what is needed to make inclusion in General Physical
Education (GPE) successful. GPE teachers without support from an APE specialist can include a student with SEN in GPE without negatively affecting the learning of peers without disabilities (Obrusnikova et al., 2003).

Attitudes towards inclusion in PE have an important role in the smooth and successful process of inclusion and the positive outcomes. Teachers believe in this philosophy and, in particular, they consider that it has a positive effect on individuals with and without SENs (Lieberman et al., 2000).

Appropriate inclusion produces many benefits however can be significantly detrimental if not implemented appropriately and with careful consideration to all students, including students with SEN. On the other hand, gender and the type of disability significantly influenced attitudes. Students without disabilities in intergraded GPE had significantly less positive attitudes towards peers with physical disabilities and significantly more positive attitudes toward peers with behavior disabilities than students in segregated GPE.

Gender and age are considered as variables which significantly influence attitude. Women have more favorable attitude than men towards students with SEN (Hodge \& Jansna, 1999; Hutzler et al., 2005; Downs \& Williams, 1994) but others found no significant gender differences (Rizzo, \& Vispoel, 1991). DePauw and Goc Karp (1990) found that older physical educators possess less positive attitudes than their younger counterparts, but other studies revealed no relationship between attitudes and age of physical educators (Rizzo \& Vispoel, 1991; Rizzo \& Wright, 1988). Attitudes of physical educators are more likely to be positive when they have more academic preparation (Block \& Rizzo, 1995; FolsomMeek \& Rizzo, 2002; Kowalski \& Rizzo, 1996; Rizzo \& Kirkendall, 1995), experience in teaching students with disabilities (Block \& Rizzo, 1995; Kozub \& Poretta, 1998; Schmidt-Gotz et al., 1994) and higher perceived competence in teaching students with disabilities (Block \& Rizzo, 1995; 
Kowalski \& Rizzo, 1996; Rizzo \& Kirkendall, 1995; Schmidt-Gotz et al., 1994).

The attitudes of current physical education teachers are very important and should be taken into consideration when making changes as they can have a direct impact on the success of the students' learning (Meegan \& MacPhail, 2006).

The aim of this study is to describe and to analyze the attitudes of physical education students and physical education teachers towards inclusion of students with physical disabilities in general physical education programs in Bulgaria in order to predict their intention and behaviors relating to inclusive education.

\section{METHODS}

Ethical approval for this research study was granted by the National Sports Academy, Social Science and Behavioral Human Research Ethics Committee.

\section{Participants}

The collection of data was completed during the second semester of the school year in 2012. Participants were in total 110 (55 females and 55 males), 50 last year university students from the National Sports Academy "Vassil Levski", Sofia, Bulgaria and 60 Bulgarian physical education teachers. An average age of LYUS is 22.65 years, and PET is 35.6 years. The data can be seen in TABLE 1. All of the participants completed the survey voluntarily.

Inclusion criteria: The last year of studying physical education in National Sports Academy and graduated with at least a Bachelors degree in Physical Education at National Sports Academy which is accredited from the Bulgarian Ministry of Education, currently teaching in a primary secondary or high school, have at least one child with a disability in his/her class.

The differences between the groups are for the teachers who graduated before 2002 because the curriculum of the courses at the National Sports Academy "Vassil Levski" includes the course "Adapted Physical Activity" (2 ECTS) which began in 2002.
Exclusion criteria: short term replacements of original teachers.

Table 1 Participants in the study

\begin{tabular}{|l|c|c|c|}
\hline & $\begin{array}{c}\text { Males } \\
\mathbf{n} \\
\text { (Mean Age) }\end{array}$ & $\begin{array}{c}\text { Females } \\
\mathbf{n} \\
\text { (Mean Age) }\end{array}$ & $\begin{array}{c}\text { Combined } \\
\text { total n } \\
\text { (Mean Age) }\end{array}$ \\
\hline LYUS & 29 & 21 & 50 \\
& $(22.6)$ & $(22.7)$ & $(22.65)$ \\
\hline PET & 26 & 34 & 60 \\
& $(35.7)$ & $(35.5)$ & $(35.6)$ \\
\hline
\end{tabular}

LYUS - last year university students

PET - physical education teachers

\section{Instrument}

The Bulgarian translated version of the questionnaire "Attitudes Toward Teaching Individuals with Physical Disabilities in Physical Education" (ATIPDPE) was used for this study. In this study the instrument was used to measure the attitudes of Bulgarian last year Bachelor students in National Sports Academy and teachers towards inclusion of students with physical disabilities in general physical education classes. The original ATIPDPE was developed by Kudlacek, Valkova, Sherrill, Myers and French (2002) in the Czech language.

Translating is a difficult task, but it is a reasonable alternative to the creation of a new instrument for the chosen culture. The importance of having an instrument that is not only translated to be reliable and valid but also meaningful in the other culture needs to be reaffirmed (Banville, Desrosiers, \& GenetVolet, 2000). The technique of translation is the back-translation technique (Brislin, 1986) and requires four bilingual translators.

After the translation, the instrument was distributed to an experimental group to see if the meaning of the questions was clear and understandable.

The questionnaire starts with the purpose of the survey, general instructions for completing the questionnaire and an example for using the rating scale while answering an item. Then part I and II of the survey is 
composed of items relating to the level of understanding of the definitions.

Part I consists of the definition of students with physical disabilities. Part II consists of definitions of inclusion. Part III is the main part of the questionnaire which is constructed in a way to include items relating to intention statements (4), behavioral beliefs (12), normative beliefs (7) and control beliefs (8). All items on the survey use 7-point Likert scale, 1 being the lowest and 7 the highest. The three components of TPB that are positioned to predict intention in the ATIPDPE questionnaire are the attitude toward behavior, subjective norm and perceived behavioral control. In addition, the ATIPDPE instrument measured three psychological components: a) Positive outcome for students, b) Negative outcome for students, and c) Negative outcome for teachers.

Enclosed with the questionnaire will be a participant information sheet providing personal information as well as information related to previous adapted physical activity experience.

\section{Questionnaire collection and scoring}

The ATIPDPE-BG was distributed and collected by Assoc. Prof. Elena Nikolova, Ph.D. at the National Sports Academy, Sofia, Bulgaria, she is the co-promoter of this research study as well as the national $\mathrm{PE}$ teachers coordinator as well, to last year students in Physical Education and Primary, Secondary and High Schools. After the translation Assoc. Prof. Elena Nikolova distributed the instrument to 10 teachers for pilot research. Afterwards when the responders answered and said that the questions were clear and understandable she distributed the instrument at the Spring Annual Meeting for current PET in April 2012. In the beginning of the meeting all of the participants were asked to fill out the questionnaire. All of the participants filled it in and in total we received 52 questionnaires. Two were dropped because the participants did not answer all questions. Enclosed with the questionnaire was a participant information sheet (PIS) providing information on the study as well as contact details, should participants have questions or require further information. Respondents remained anonymous and were identified only by their age, students and teachers, and gender. Respondents were given the option to complete the questionnaire or not. They were in no way penalised if they did or did not complete the questionnaire.

The scoring system required the use of a 7-point scale for one construct and a -3 to +3 scale for the other construct. Specifically, behavioral belief evaluation scores, normative belief strength scores, and control belief power scores were transformed using the Statistical Software from unidirectional $(1,2$, $3,4,5,6,7)$ to bidirectional $(-1,-2,-3,0,+1$, $+2,+3)$ scoring.

Table 2 Sample items from the attitudinal scale

Behavioral belief (outcome belief)

Likelihood

Inclusion will have a positive effect on the development of personalities of students with

physical disabilities (e.g. self esteem, feeling of belonging, etc.)

Extremely Unlikely Outcome: :____ Extremely Likely

$\begin{array}{llllllll}\text { Outcome } & 1 & 2 & 3 & 4 & 5 & 6 & 7\end{array}$ 
Evaluation

Positive effect on the development of personalities of students with physical disabilities is:

Extremely Bad Outcome: : Extremely Good Outcome

$\begin{array}{lllllll}-3 & -2 & -1 & 0 & 1 & 2 & 3\end{array}$

\section{Data analysis}

To compare the attitudes of the two groups of students and teachers from Bulgaria we were used a one way analysis of variance (ANOVA). Intention toward behavior can be inferred from the summative behavioral belief index. Scores which show an opinion of likelihood (that the outcome will occur) were calculated based on a 1 to 7 scale. Scores indicating an evaluation of a good or bad outcome were calculated on a -3 to +3 scale.

A oneway analysis of variance (ANOVA) was used to compare the attitudes of the two groups of students and teachers from Bulgaria. A statistical analysis program (SPSS PC 13.0 software) was used to analyze the data and to determine if there are any significant differences between students in their intention to include participants with physical disabilities into general activities and hold the corresponding behavioral belief.

\section{RESULTS}

The sample for the study considered students from the National Sports Academy, "Vassil Levski", Sofia, Bulgaria (50) and Bulgarian physical education teachers (60).

Results from the demographic data study (TABLE 3 ) found that there were the same number of female participants (55) and male participants (55) in the study. Approximately $25 \%$ of participants in both groups LYUS and PET courses reported having some personal experience with people with physical disabilities (PD). Only one teacher from the combined participants found this experience to be not good, while approximately $19 \%$ in both groups found their experiences to be satisfactory, only $2 \%$ of
LYUS and $8.3 \%$ of PET recorded of very good experiences and $76 \%$ and $71.7 \%$ respectively noted that their experience with persons with physical disabilities was outstanding. Of the two subject majors, there was a considerable difference among the number of students who had completed a course at University relating to adapted physical activity (APA). While only $94 \%$ of LYUS had completed such a course, $50 \%$ within PET had completed a related course. It was also reported that $48 \%$ of LYUS and $25 \%$ of PET had not received any form of information related to physical education and sport for individuals with physical disabilities outside of their University studies. When asked how competent the participants felt at the current time to teach physical education to students with physical disabilities, LYUS replied with $52 \%$ indicating not at all, $44 \%$ indicating somewhat, and only $4 \%$ indicating that they felt very prepared. Of the PET, $26.7 \%$ felt not at all competent, $71.7 \%$ felt somewhat competent, and only $1.7 \%$ felt very competent. Responses varied somewhat when asked about their perceived competence to teach students with PD after graduation. Of LYUS and PET respectively $2 \%$ and $20 \%$ replied that they would feel not at all competent, $78 \%$ and $60 \%$ replied that they would feel somewhat competent, while $20 \%$ and $1.7 \%$ replied that they would feel very confident to teach students with physical disabilities in physical education after completing their teacher preparation course, $18.3 \%$ of PET respectively noted that their perceived competence to teach students with PD after graduation was outstanding. 
Table 3 Demographic Data - LYUS and PET.

\begin{tabular}{|c|c|c|}
\hline Variable & $\underset{\%}{\text { LYUS }}$ & $\begin{array}{c}\text { PET } \\
\%\end{array}$ \\
\hline Female & 38.2 & 61.8 \\
\hline Male & 52.7 & 47.3 \\
\hline Personal experience with people with PD & 22.0 & 28.3 \\
\hline $\begin{array}{l}\text { Evaluation of experience with PD: } \\
\qquad \text { Not good } \\
>\text { Satisfactory } \\
>\text { Very good } \\
>\text { Outstanding }\end{array}$ & $\begin{array}{l}2.0 \\
20.0 \\
2.0 \\
76.0\end{array}$ & $\begin{array}{c}1.7 \\
18.3 \\
8.3 \\
71.7\end{array}$ \\
\hline Completion of a university APA course & 94.0 & 50.0 \\
\hline $\begin{array}{l}\text { Provided with information on PD and physical education outside of } \\
\text { university }\end{array}$ & 52.0 & 75.0 \\
\hline $\begin{array}{l}\text { Perceived competence to teacher participants with PD today: } \\
\quad>\text { Not at all } \\
>\text { Somewhat } \\
>\text { Very }\end{array}$ & $\begin{array}{c}52.0 \\
44.0 \\
4.0\end{array}$ & $\begin{array}{c}26.7 \\
71.7 \\
1.7\end{array}$ \\
\hline $\begin{array}{l}\text { Perceived competence to teach participants with PD after graduation: } \\
\quad \text { Not at all } \\
>\text { Somewhat } \\
>\text { Very } \\
>\text { Outstanding }\end{array}$ & $\begin{array}{c}2.0 \\
78.0 \\
20.0\end{array}$ & $\begin{array}{c}20.0 \\
60.0 \\
1.7 \\
18.3\end{array}$ \\
\hline
\end{tabular}

Legend:

APA - adapted physical activity;

LYUS - last year university students;

PET - physical education teachers;

$P D$ - physical disabilities.

Note: Evaluation of experience and intention after the graduation with $P D$ had low response rates as most participants did not complete this question if they had no experience with people with PD.

TABLE 4 displays that no significant differences were found between gender during this study. In relation to overall attitudes towards teaching students with physical disabilities in physical education, although the data shows that both groups have all most the same responses, there were no significant differences between the groups in relation to attitude $(\mathrm{F}=0.11, \mathrm{p}=0.74)$, subjective norm $(\mathrm{F}=0.11, \mathrm{p}=0.74)$, perceived behavioral control $(\mathrm{F}=0.02, \mathrm{p}=$ $0.89)$, or intention $(\mathrm{F}=0.01, \mathrm{p}=0.93)$.

In relation to overall attitudes towards teaching students with physical disabilities in physical education, although the data shows that LYUS have higher overall responses than PET, there were significant differences between the groups in relation to attitude $(\mathrm{F}=$ 
18.75, $\mathrm{p}=0.000)$, subjective norm $(\mathrm{F}=6.45$, $\mathrm{p}=0.013)$, perceived behavioral control $(\mathrm{F}=$ 12.72, $\mathrm{p}=0.001)$, and intention $(\mathrm{F}=3.70, \mathrm{p}=$ 0.057). Overall, on a scale with a maximum score of 14, subjective norm was found to be very low $($ LYUS $=7.22$, PET $=3.87)$, but intention did high (LYUS $=22.58$, PET $=$ 20.25), while perception of behavioral control was also found to be relatively lower (LYUS $=5.98$, PET $=3.87$; maximum score of 14 ). Results can be seen in TABLE 5.

Table 4 Comparison of genders separate for LYUS and PET.

\begin{tabular}{|l|c|c|c|c|c|c|}
\hline & \multicolumn{2}{|c|}{ LYUS } & \multicolumn{2}{c|}{ PET } & \multirow{2}{*}{ F } & \multirow{2}{*}{ p } \\
\cline { 2 - 7 } & Female & Male & Female & Male & & \\
& Mean & Mean & Mean & Mean & & \\
& $($ SD) & $($ SD) & $($ SD) & $($ SD) & & \\
\hline Attitudes & 28.86 & 30.45 & -14.18 & -9.69 & 0.11 & 0.74 \\
& $(55.25)$ & $(47.70)$ & $(54.39)$ & $(46.74)$ & & \\
\hline Subjective Norm & 7.81 & 6.79 & 5.35 & 5.00 & 0.11 & 0.74 \\
& $(4.52)$ & $(4.31)$ & $(3.99)$ & $(3.97)$ & & \\
\hline Perceived Behavioral Control & 6.57 & 5.55 & 3.91 & 3.81 & 0.02 & 0.89 \\
& $(3.83)$ & $(3.18)$ & $(2.84)$ & $(2.67)$ & & \\
& 22.57 & 22.59 & 20.32 & 20.15 & 0.01 & 0.93 \\
& $(5.42)$ & $(5.90)$ & $(7.12)$ & $(6.60)$ & & \\
\hline
\end{tabular}

$p=<0.05$ statistical significance

PET - physical education teachers

LYUS - last year university students;

Table 5 Comparison between LYUS and PET.

\begin{tabular}{|l|c|c|c|c|}
\hline & $\begin{array}{c}\text { LYUS } \\
\text { Mean } \\
\text { (SD) }\end{array}$ & $\begin{array}{c}\text { PET } \\
\text { Mean } \\
\text { (SD) }\end{array}$ & F & p \\
\hline Attitudes & 29.78 & -12.23 & 18.75 & 0.000 \\
& $(50.46)$ & $(50.84)$ & & \\
\hline Subjective Norm & 7.22 & 5.20 & 6.45 & 0.013 \\
& $(4.39)$ & $(3.95)$ & & \\
\hline Perceived Behavioral Control & 5.98 & 3.87 & 12.72 & 0.001 \\
& $(3.47)$ & $(2.75)$ & & 0.057 \\
\hline Intention & 22.58 & 20.25 & 3.70 & \\
& $(5.64)$ & $(6.84)$ & & \\
\hline
\end{tabular}

$p=>0.05$ statistical significance

LYUS - last year university students;

PET - physical education teachers; 
TABLE 6 depicts component loadings of the 12 items. Each of the items loaded higher then the 0.35 cut off point. Most items showed excellent loadings (above 0.70) with the exception of two items (item $11=0.35$, and item $12=0.63$ ). Thus we can conclude that the described attitudinal scale has a sound structure, which is comparable with the structure of the reviously studied original instrument ATIPDPE. Cronbach's alpha reliability coefficient normally ranges between 0 and 1 . The closer Cronbach's alpha coefficient is to 1.0 the greater the internal consistency of the items in the scale. The revised scale has a sound structure and an internal consistency of 0.813 , which indicates a high level of internal consistency for our scale with this specific sample and therefore it is recommended to use it.

Table 6 Component loadings, eigenvalues and percentages of variance using principal components extraction with varimax rotation for total composite scores.

\begin{tabular}{|l|c|c|c|}
\hline Item \# & \multicolumn{3}{|c|}{ Varimax components } \\
\hline Positive outcomes for students & .82 & & \\
1 & .86 & & \\
3 & .78 & & \\
5 & .76 & & \\
6 & .73 & & \\
9 & .83 & & \\
10 & & & .80 \\
& & & .35 \\
\hline Negative outcomes for students & & & .63 \\
7 & & .88 & \\
8 & & & \\
11 & & & \\
12 & & & \\
\hline Negative outcomes for teachers & & & \\
2 & & & \\
4 & & & \\
\hline
\end{tabular}

In order to predict the intention of participants to include students with physical disabilities into general physical education classes, a multiple regression analysis was performed. Results found that the only significant predictor for intention was attitude. Attitude was found to be the strongest predictor of intention with $43 \%$ predictability $\left(\mathrm{r}^{2}=0.435\right)$. When combining subjective norm and attitudes, prediction decreased to $6 \%\left(\mathrm{r}^{2}=0.066\right)$. Perceived behavioral control also provided an effect on prediction of intention, and when combined with attitude and subjective norm, prediction was decreased to $31 \%\left(r^{2}=0.318\right)$.
Table 6 Prediction of intention using multiple regression analysis

\begin{tabular}{|c|c|c|c|c|c|}
\hline Step & Variability & $\mathbf{R}$ & $\mathbf{r}^{2}$ & $\boldsymbol{\beta}$ & df \\
\hline 1 & Attitude & 0.066 & 0.435 & 0.066 & 1 \\
\hline 2 & $\begin{array}{l}\text { Attitude + } \\
\text { Subjective } \\
\text { Norm }\end{array}$ & $\begin{array}{c}- \\
0.033\end{array}$ & 0.066 & $\begin{array}{c}- \\
0.029\end{array}$ & 3 \\
\hline 3 & $\begin{array}{l}\text { Attitude + } \\
\text { Subjective } \\
\text { Norm }+ \\
\text { Perceived } \\
\text { Behavioral } \\
\text { Control }\end{array}$ & $\begin{array}{c}- \\
0.159\end{array}$ & 0.318 & $\begin{array}{c}- \\
0.142\end{array}$ & 2 \\
\hline
\end{tabular}




\section{DISCUSSION}

One of the main barriers to the inclusion of children with disabilities into regular physical education is the attitude of teachers. These attitudes toward inclusion of children with disabilities can arise from insufficient knowledge or lack of experience. An obvious solution would be to improve these two elements (knowledge and experience).

The purpose of this study was to describe the attitudes and predictors of intentions towards inclusion of students with physical disabilities in general physical education classes of Bulgarian physical education teachers and last year University students.

Discrimination against children with disabilities stems from multiple sources, including attitudes, subjective norms, perceived behavioral control, intention, which in turn can lead to stigma and entrenched social exclusion. Their participation is further limited by multiple barriers, including lack of access to the physical environment and to information and communication; lack of adequate legislation, lack of public policies and monitoring mechanisms; and lack of training for teachers and other service providers.

Hodge, et al. (2004), found that teachers expressed mostly favorable beliefs towards teaching students with disabilities, while Block and Obrusnikova (2007) found that general physical education teachers had negative feelings toward inclusion. This current study found that PE teachers held more negative attitudes than LYUS (PET mean $=-12.23$, LYUS mean $=29.78$ ) towards including students with physical disabilities into general physical education classes. Overall, on a scale with a maximum score of 14 , subjective norm was found to be not very high (LYUS $=7.22$, PET $=5.20$ ), as did intention $($ LYUS $=22.58$, PET $=20.25)$, while perception of behavioral control was also found to be lower $($ LYUS $=5.98$, PET $=$ 3.87; maximum score of 14), thus suggesting that while LYUS demonstrate high intentions to include students with physical disabilities in their future physical education programs and confidence in regards to conforming to the social expectations to perform such behaviors, their perceived behavioral control suggests that they do not feel that they have full control over factors that may affect the inclusion process.

One aim of this study was to compare the attitudes of participants by gender. No significant differences were found. It is interesting to note that when looking at results for LYUS (female Mean $=28.86$, male Mean $=30.45$ ) held higher attitudes than the PET (female Mean $=-14.18$, male Mean $=-9.68)$. Although this is not a significant difference, it is possible to consider justifications for this result such as greater amount of inclusion in schools, practical experience, greater preparation and confidence. While Avramidis et al (2000) found that there were slightly more positive attitudes towards inclusion from female teachers compared to males, this finding was also supported by Meegan and MacPhail (2006) who found that female teachers in Ireland held more positive attitudes than did male educators in relation to teaching students with special educational needs.

Demographic results showed that LYUS had a higher rate of completion of a University course related to students with disabilities than PET. While one might assume that this would produce more positive attitudes, this is not the case. A suggested reason might be that LYUS are more optimistic about the possibilities of teaching, while PET are more realistic and have experienced the challenges of teaching, and the course "Adapted Physical Activity" started in 2002 as part of the compulsory courses for all faculties in National Sports Academy "Vassil Levski", Sofia, Bulgaria. Perhaps this result can be related to findings by Avramidis et al. (2000), who found that younger teachers and teachers with fewer years experience held more positive attitudes towards inclusion than did their older, more experienced peers (Avramidis et al., 2000). While the literature emphasises the importance of academic preparation relating 
to people with disabilities and school programs, in the form of lectures, discussions, viewing successful inclusion programs, interaction and participation with students with disabilities in order to acquire understanding, meaningful, positive and practical experiences and hence develop more positive attitudes towards inclusion of students with physical disabilities in general educational settings (Hodge et al., 2002; Tripp \& Rizzo, 2006).

When considering the demographic data that was retrieved from this study, it is interesting that while $52 \%$ of LYUS expressed that they felt not at all competent to teach children with physical disabilities at the present time, when asked how competent they assume they will feel after graduation, 98\% responded that they would feel somewhat or very competent, a positive improvement from the previous responses. When considering responses from PET, their view about their competence to teach students with physical disabilities was $20 \%$. They expressed that they will feel not at all competent after graduation, and only $1 \%$ stating that they will feel very competent. These results suggest that the LYUS feel more competent and more confident to implement inclusive programs than PET, and the reason could be that the LYUS have not been teaching alone and all of them pass the APA course, which started in 2002.

Previous studies have also investigated the effect of type and severity of disability on attitudes of teachers towards teaching students with disabilities. Yuen and Westwood (2007) found that negative attitudes were particularly present in relation to the teaching of students with behavioral problems, severe hearing or visual disabilities as well as intellectual disabilities. Avramidis et al. (2000) found that the severity of the disability had a significant impact upon the teachers' attitudes, and that students with more severe disabilities received a less favorable attitude towards inclusion by the teacher, and that the teachers held less positive attitudes towards those children with emotional and behavioral disabilities in comparison to other types of disabilities. Although this would be an interesting variable to consider, the ATIPDPE instrument used during this research focuses solely of students with physical disabilities. It does not mention specific disabilities or severity of disabilities and therefore no conclusions can be drawn from this study regarding this.

In relation to predicting intentions of participants to perform certain behaviors, in this case to include students with physical disabilities in physical education programs, attitudes were found to be the strongest predictor with $43 \%$ predictability. The literature lends support to the notion that it is possible to predict behaviors of individuals from their attitudes towards performing such behaviors and that behavior specific attitudes have been shown to correlate well with the corresponding behavior (Ajzen, 2005). The current research provides evidence that attitude towards performing such a behavior has a $43 \%$ correlation towards the intention to carry out this behavior, and hence this provides some support to the notion mentioned above that by measuring attitudes, it is possible to somewhat predict the intention of an individual to perform a certain behavior. This study found that when combining attitude with subjective norm and perceived behavioral control, this accounts for $32 \%$ of predictability of intention. When comparing this with other literature whose results show 17 to $69 \%$ of variance (Sheeran \& Taylor, 1999), 49\% (Norman, Connor \& Bell, 1999), or 45\% (Hagger, Chatzisarantis $\&$ Biddle, 2002), the explanation of predictability of intention by only three components of the theory of planned behavior in this study is low.

Responses to the ATIPDPE instrument have been influenced by the following a) internal variances within groups, by looking at two different base groups and then comparing between and within these, it was difficult to understand the effect of factors such as confidence, experience, and other such factors which may have an impact upon participant responses and attitudes, b) demographic data found that the majority of 
LYUS had completed a university course relating to teaching students with disabilities and the majority of PET had received information about this outside of University. It could then be suggested that the participants may not have had the chance of teaching students with physical disabilities in physical education, c) the hypothetical nature of the ATIPDPE instrument may not evoke accurate decision making while completing the survey. This may therefore result in inaccurate responses, or responses that may be socially expected rather than true personal beliefs and attitudes, because the real inclusion in Bulgaria still does not exist.

Recommendations for future research may include a larger sample size, so as to ensure suitable data for statistical analysis. This research study was only conducted in one university in Bulgaria and schools in Sofia, in order to achieve a stronger overall understanding of attitudes of the participants towards inclusion within Bulgaria it would be necessary to complete similar research across the country. The present results indicate that the ATIPDPE-BG can be a reliable instrument that measures $\mathrm{PE}$ teachers' attitudes and that the theory of planned behavior can provide a sound theoretical framework for the study of the attitudes of physical educators. More studies about attitudes and inclusion are suggested, so we can observe the ongoing participation of children with disabilities and SEN in PE classes in general schools.

\section{CONCLUSION}

Inclusion is an increasingly observed phenomenon throughout the world today. It is therefore necessary to have competent and confident teachers to implement successful programs ensuring that all students receive equal and adequate opportunities for developing and learning within a safe and encouraging environment. While overall attitudes LYUS in National Sports Academy, Sofia are generally positive according to belief statement responses. This can be acknowledged as a possibility because LYUS have not faced direct contact in PE class with children with disabilities. Their experience is like an internship in selected schools. The number of participants who expressed that they do not feel competent at the present time and will not feel competent after graduation is worrisome. While it was found that overall attitudes of students were positive, but attitudes of teachers were not positive of intentions towards inclusion. A possible reason may be that the late start in 2002 includes the course "Adapted Physical Activity".

No significant differences among gender were seen.

It is time to develop a comprehensive training system for teachers, educators and social workers to better prepare them to work with children with disabilities.

To participate the individuals who need special training as active and productive people in the society, if and only if it is possible with education. The principle of equality of opportunity in education is to prepare individuals in their training needs and in accordance with specifications in the appropriate environment to ensure training requirements.

The Bulgarian education system must have continuous information about what happens in the process of inclusion of children with disabilities in mainstream schools. This involves conducting continuous sociological, psychological, economic, socioanthropological, interdisciplinary studies of mutual influence that afford both children with and without disabilities, attitudes and emotions of parents of both groups of children, etc.

\section{REFERENCES}

Ajzen, I. (1991). The theory of planned behavior. Organizational Behavior and Human Decision Processes, 50, 179-211.

Ajzen, I. (2005). Attitudes, Personality and Behavior (2nd ed.) Berkshire, England: Open University Press.

Ajzen, I., \& Driver B.L. (1992). Application of the theory of planned behavior to leisure choice. Journal of Leisure Research, 24, 207-224. 
Avramidis, E., \& Norwich, B. (2002).

Teachers' attitudes towards

integration/inclusion: a review of the literature. European Journal of Special

Needs Education, 17(2), 129-147.

Banville, D., Desrosiers, P., \& Genet-Volet, Y. (2000). Translating questionnaires and inventories using a cross-cultural translation technique. Human Kinetics Publishers, INC. 374-387.

Block, M.E., \& Rizzo, T.L. (1995). Attitudes and attributes of physical educators associated with teaching individuals with severe and profound disabilities. Journal of The Association for Persons with Severe Handicaps, 20(1), 80-87.

Block, M.E., \& Vogler, E.W. (1994). Inclusion in regular physical education: The research base. Journal of Physical Education, Recreation, and Dance, 65(1), 40-44.

Block, M.E., \& Zeman, R. (1996). Including students with disabilities in regular physical education: Effects on nondisabled children. Adapted Physical Activity Quarterly, 13, 38-49.

Brislin, R.W. (1986). The wording and translation of research instruments. In J. Lonner \& J.W. Berry (Eds.). Field methods in cross-cultural research, 137-164.

DePauw, K.P., \& Goc Karp, G. (1990). Attitudes of selected college students toward including disabled individuals in integrated settings. In G. Doll-Tepper, C. Dahms, B. Doll, \& H. Von Selzam (Eds.), Adapted Physical Activity (pp. 149-158). Berlin.

Downs, P. \& Williams, T. (1994). Student attitudes toward integration of people with disabilities in activity settings. Adapted Physical Activity Quarterly, 11, 32-43.

Folsom-Meek, S.L., \& Rizzo, T.L. (2002).Validating the physical educators' attitude toward eaching individuals with disabilities III (PEATID III) survey for future professionals. Adapted Physical Activity Quarterly, 19, 141-154.

Hodge, S. R. \& Jansma, P. (1999). Effects of contact time location of practicum experiences on attitudes of physical education majors. Adapted Physical Activity Quarterly, 16, 48-63.

Hutzler, Y., Zach, S., \& Gafni, O. (2005). Physical education students' attitudes and self-efficacy towards the participation of children with special needs in regular classes. European Journal of Special Needs Education, 20(3), 309-327.

Kowalski, E.M., \& Rizzo, T.L. (1996).Factors influencing pre-service student attitudes toward individuals with disabilities. Adapted Physical Activity Quarterly, 13, 180-196.

Kozub, F., \& Porretta, ZD. (1988). Interscholastic coaches' attitudes toward integration of adolescents with disabilities. Adapted Physical Activity Quarterly, 15, 328-344.

Krech, D., R.S. Crutchfield, \& E.L. Ballachey (1962). Individuals in Society. New York: McGraw-Hill.

Kudláček, M. (2001). An attitude toward inclusion instrument based on the theory of planned behaviors for prospective Czech physical educators. Doctoral dissertation, Texas Women`s University, Denton.

Kudláček, M. (2007). Components of Attitudes toward Inclusion of Students with Physical Disabilities in Physical Education in the revised "ATIPDPE - R" Instrument/Scale for Prospective Czech Educators. Acta Universitatis Palackianae Olomucensis Gymnica, 37(1), 13-18.

Lieber, J., Capell, K., Sandall, S., Wolfberg, P., Horn, E., \& Bechman, P. (1998). Inclusive preschool programs: teacher beliefs and practices. Early Childhood Research Quarterly, 13, 87-105.

Lieberman, L.J., Dunn, J.M., van der Mars, H., \& McCubbin, J. (2000). Peer tutors $\square$ effects on activity levels of deaf students in inclusive elementary physical education. Adapted Physical Activity Quarterly, 17, 20-39.

Meegan, S., \& MacPhail, A. (2006). Irish physical educators" attitude toward teaching students with special educational needs. European Physical Education Review, 12(1), 75-97. 
Mrug, S., \& Wallander, L.J. (2002). Self Concept of Young People with Physical Disabilities: does integration play a role? International Journal of Disability, Development and Education.Vol.49, No. 3, 267-274.

National Statistical Institute, 2011, Retrieved from http://www.nsi.bg/otrasaleventbg.php?n=1213\&otr $=22$

Obrusnikova, I., Block, M.E., \& Válková, H. (2003). Impact of inclusion in GPE on students without disabilities. Adapted Physical Activity Quarterly, 20, 230-245.

Peck, C., Carlson, P., \& Helmstetter, E. (1992). Parent and teacher perceptions of outcomes for typically developing children enrolled in integrated early childhood programs: a state-wide survey. Journal of Early Intervention, 16, 53-63.

Rizzo, T. \& Vispoel, W.P. (1991). Physical educators' attributes and attitudes toward teaching students with handicaps. Adapted Physical Activity Quarterly, 8, 4-11.

Rizzo, T. L., \& Kirkendall, D. R. (1995). Teaching students with mild disabilities: what affects attitudes of future physical educators? Adapted Physical Activity Quarterly, 12, 205-216.
Romer, L., \& Haring, N. (1994). 'The social participation of students with deaf blindness in educational settings', Education and Training in Mental Retardation and Developmental Disabilities, 29, 134-144.

Salisbury, C., Gallucci, C., Palombaro, M., \& Peck, C. (1995). Strategies that promote social relations among elementary students with and without severe disabilities in inclusive schools. Exceptional Children, 62, 125-137.

Schmidt-Gotz, E., Doll-Tepper, G., \& Lienert, C. (1994). Attitudes of university students and teachers toward integrating students with disabilities in regular physical education. Physical Education Review, 17, 43-57.

Sherrill, C. (2004). Adapted Physical Activity, Recreation and Sport: Crossdisciplinary and Lifespan (6th ed.). New York, NY: McGraw-Hill Companies. Vogler, E.W., Koranda, P., \& Romance, T. (2000). Including a child with severe cerebral palsy in physical education: A case study. Adapted Physical Activity Quarterly, 9, 316-329.

Corresponding author's e-mail address: annavlpetkova@gmail.com

\section{EINSTELLUNGEN VON STUDIERENDEN DES LEHRAMTS FÜR BEWEGUNGSERZIEHUNG (LETZTES UNIVERSITÄTSJAHR) UND BEWEGUNGSERZIHERINNEN GEGENÜBER DEM UNTERRICHTEN VON KINDERN MIT PHYSICHEN BEHINDERUNGEN IN REGELKLASSEN IN BULGARIEN}

Einstellungen von Lehrpersonen sind wichtige Verhaltensdeterminanten in Erziehungssettings (Avramidis \& Norwich, 2002), und die laufende Diskussion weist darauf hin, dass es möglich ist, das Verhalten aus der Planungsabsicht (Intention) vorherzusagen (Ajzen, 2005). Die Absicht dieser Studie war es, die Einstellungen und Prediktoren der Intention von Bewegungserzieher/innen und Studierenden des Faches Sport gegenüber der Inklusion von Schüler/innen mit physischen Behinderungen in Regelklassen des Sportunterrichts Bulgariens zu beschreiben. Das ATIPDPE-R 
wurde als Instrumentarium für die Einstellungsmessung der der Studierenden im letzten Jahr der Nationalen „Vassil Levski” - Sportakademie, Sofia, Bulgarien, und der Lehrpersonen verwendet. Insgesamt nahmen 110 (55 weibliche und 55 männliche) Teilnehmer/innen teil, 50 Studierende im letzten Jahr und 60 Bewegungserzieher/innen. Das Durchschnittsalter der Studierenden lag bei 22,65 Jahren, das der Bewegungserzieher/innen 35,6, Jahre. Es wurde das Software Package SPSS 13.0 zur Datenauswertung der Resultate verwendet, bei der eine einfaktorielle ANOVA und eine multiple Regressionsanalyse gerechnet wurden. Es zeigten sich durchgehend positive Einstellungen für die Studierenden im Gegensatz zu den Lehrpersonen, allerdings wurden keine signifikanten Unterschiede zwischen männlichen und weiblichen gefunden $(F=0.11, p=0.74)$. Einstellungen stellten sich als stärkste Prädiktoren für die Intentionen dar, wobei $43 \%$ der Varianz $\left(r^{2}=0.44\right)$ berechnet werden konnten.

Schlüsselwörte: Einstellungen, Inklusion, Bewegungserzieher/innen, Bewegungserziehung, Schüler/innen mit Behinderungen und mit besonderen Bedürfnissen, physische Behinderung

(Résumé)

\section{ATTITUDES DES ÉLÈVES D'ÉDUCATION PHYSIQUE (DERNIERE ANNÉE UNIVERSITAIRE) ET DES ENSEIGNANTS D'ÉDUCATION PHYSIQUE ENVERS L'ENSEIGNEMENT DES ENFANTS HANDICAPÉS PHYSIQUES EN COURS GÉNÉRAL D'ÉDUCATION PHYSIQUE EN BULGARIE}

Les attitudes des enseignants sont un déterminant important du comportement en milieu scolaire (Avramidis \& Norwich, 2002), et les études actuelles suggèrent qu'il est possible de prédire le comportement à partir des intentions (Ajzen, 2005). Le but de cette étude était de décrire les attitudes et les prédicteurs de l'intention à l'égard de l'inclusion des élèves avec handicaps physiques dans des classes générales d'éducation physique bulgares ainsi qu'auprès d'étudiants de dernière année universitaire. L'instrument ATIPDPE-R a été utilisé pour mesurer les attitudes des étudiants en dernières années du National Sports Academy "Vassil Levski", Sofia, en Bulgarie et des professeurs bulgares d'éducation physique. Les participants étaient 110 au total ( 55 femmes et 55 hommes), 50 étudiants étaient en dernières années universitaires et 60 professeurs d'éducation physique. La moyenne d'âge des étudiants de dernière année était de 22.65 ans, et des enseignants d'éducation physique 35.6 ans. Le logiciel SPSS 13.0 a été utilisé pour analyser les résultats par ANOVA à un facteur et par analyse de régression multiple. L'ensemble des attitudes positives a été démontée pour les étudiants, contrairement aux enseignants, mais aucune différence significative entre les hommes et les femmes ont été trouvé $(\mathrm{F}=0.11, \mathrm{p}=0.74)$. Les attitudes se sont révélées être le meilleur prédicteur des intentions, ce qui représente $43 \%$ de la variance $\left(\mathrm{r}^{2}=0.44\right)$.

Mots Clés : attitudes, inclusion, éducateurs sportifs, éducation physique, étudiants handicaps et besoins éducatifs spécifiques, déficiencies motrices 


\section{ОТНОШЕНИЕ СТУДЕНТОВ (НА ПОСЛЕДНЕМ ГОДУ ОБУЧЕНИЯ) И ПРЕПОДАВАТЕЛЕЙ ФИЗИЧЕСКОГО ВОСПИТАНИЯ К ОБУЧЕНИЮ ДЕТЕЙ С ФИЗИЧЕСКИМИ НЕДОСТАТКАМИ НА ОБЩИХ УРОКАХ ФИЗКУЛЬТУРЫ В БОЛГАРИИ}

Позиция учителей является важным определяющим фактором поведения в образовательной системе установок (Avramidis \& Norwich, 2002). Цель исследования состояла в том, чтобы описать отношение и позицию болгарских преподавателей физического воспитания и студентов по отношению к включению учащихся с ограниченными физическими возможностями в общие уроки физкультуры. В исследовании приняли участие студенты Национальной академии спорта "Василий Левски" (г. София, Болгария) и болгарские преподаватели физической культуры. Участников в общей сложности было 110 (55 женщин и 55 мужчин), 50 студентов на последнем году обучения и 60 преподавателей физической культуры. Средний возраст студентов $\quad 22,65$ лет, а учителей физкультуры 35,6 лет. Для анализа результатов был использован Пакет Программного обеспечения SPSS 13,0 с помощью одностороннего ANOVA и множественного регрессионного анализа. Общие положительные отношения были выражены больше студентами, в отличие от учителей, а между мужчинами и женщинами не было найдено никаких существенных различий $(\mathrm{F}=0,11, \mathrm{p}=0,74)$.

Ключевые слова: отночения, включение в физическое образование, физическое воспитание, студенты с ограниченными возможностями и особыми потребностями, инвалидность

(Resumen)

\section{ACTITUDES DE LOS ESTUDIANTES DE EDUCACIÓN FÍSICA (ÚLTIMO CURSO ACADÉMICO) Y PROFESORES DE EDUCACIÓN FÍSICA HACIA LA ENSEÑANZA DE NIÑOS CON DISCAPACIDAD FÍSICA EN LAS CLASES DE EDUCACIÓN FÍSICA GENERAL EN BULGARIA}

Las actitudes de los docentes son un factor determinante del comportamiento en entornos educativos (Avramidis \& Norwich, 2002), y la discusión actual sugiere que es posible predecir el comportamiento desde las intenciones (Ajzen, 2005). El propósito del estudio fue describir las actitudes y los predictores de la intención hacia la inclusión de alumnos con discapacidades físicas en las clases de educación física general de profesores búlgaros de educación física y estudiantes universitarios de último año. El instrumento ATIPDPE-R se utilizó para medir las actitudes de los estudiantes de último año de la Academia Nacional de Deportes "Vassil Levski" de Sofía (Bulgaria) y profesores de educación física búlgaros. Los participantes fueron 110 en total (55 mujeres y 55 varones), 50 estudiantes universitarios de últimos años y de 60 profesores de educación física. La edad media de los últimos años de los estudiantes universitarios fue de 22,65 años, y los profesores de educación física 35,6 años. El paquete de software SPSS 13,0 se utilizó para analizar los resultados mediante ANOVA de una vía y análisis de regresión múltiple. En general, se mostraron actitudes positivas de los estudiantes, en contraste con los profesores, aunque no se encontraron diferencias significativas entre hombres y mujeres $(F=0,11, p=0,74)$. Las actitudes resultaron ser el predictor más fuerte de las intenciones, lo que representa el $43 \%$ de la varianza $\left(\mathrm{r}^{2}=0,44\right)$. 
Palabras clave: actitudes, inclusión, educadores físicos, educación física, los estudiantes con discapacidades y necesidades educativas especiales, discapacidad fisica.

(Resumo)

\section{ATITUDES DOS ESTUDANTES DE EDUCAÇÃO FÍSICA (ÚLTIMO ANO DA UNIVERSIDADE) E DOS PROFESSORES DE EDUCAÇÃO FÍSICA FACE AO ENSINO DE CRIANÇAS COM DEFICIÊNCIAS FÍSICAS NASS AULAS REGULARES DE EDUCAÇÃO FÍSICA NA BULGÁRIA}

As atitudes dos professores são um importante determinante do comportamento em contextos educacionais (Avramidis \& Norwich, 2002), e a discussão em curso sugere que é possível predizer o comportamento a partir das intenções (Ajzen, 2005). O objectivo do estudo foi descrever atitudes e os preditores das intenções face à inclusão de estudantes com deficiência física nas classes regulares de educação física, na Bulgária, leccionadas por professores de educação física e estudantes do último ano do curso. O questionário ATIPDPE-R foi utilizado para medir as atitudes dos estudantes do último ano da National Sports Academy "Vassil Levski", Sofia, Bulgária e dos professores Búlgaros de educação física. O total de participantes foi de 110 (55 femininos e 55 masculinos), 50 estudantes do último ano e 60 professores de educação física. A média de idades dos estudantes do último ano é de 22,65 anos e a dos professores de educação física de 35,6 anos. Foi utilizado o pacote de software estatístico SPSS 13.0 para analisar os resultados através da realização de uma one-way ANOVA e de uma análise de regressão múltipla. Atitudes globais positivas foram encontradas para os estudantes em contraste com os professores, no entanto, não foram encontradas diferenças estatisticamente significativas entre masculinos e femininos $(\mathrm{F}=0,11$, $\mathrm{p}=0,74)$. As atitudes foram identificadas como sendo os preditores mais fortes das intenções, explicando $43 \%$ da variância $\left(\mathrm{r}^{2}=0,44\right)$.

Palavras-Chave: Atitudes, inclusão, professores de educação física, educação física, estudantes com deficiência e NEE, deficiência física 